European Journal of Adapted Physical Activity, 1(1), 51-61

(C) European Federation of Adapted Physical Activity, 2008

\title{
PERCEIVED COMPETENCE AND SOCIAL ACCEPTANCE ASSESSMENT IN PORTUGUESE YOUNG STUDENTS WITH AND WITHOUT DOWN SYNDROME: A PRELIMINARY ANALYSIS
}

\author{
Maria João Campos \\ José Pedro Ferreira \\ Pedro Miguel Gaspar \\ Centro de Estudos Biocinéticos, Laboratório de Psicologia do Desporto e do \\ Exercício, Faculdade de Ciências do Desporto e Educação Física, \\ Universidade de Coimbra, Portugal \\ José Irineu Gorla \\ Departamento de Estudos da Atividade Física Adaptada, Faculdade de Educação Física, \\ Universidade Estadual de Campinas, São Paulo, Brasil
}

The study of self-perceptions in groups with disability is an emergent area of research in Portugal and additional evidence is needed concerning Perceived Competence and Social Acceptance of young students with Down Syndrome (DS). The main purpose of this research was to examine the reliability of a Portuguese version of the Dutch Pictorial Scale of Perceived Competence and Social Acceptance (Vermeer \& Veenhof, 1997) to be used in children with and without DS. A second purpose was to assess hypothetical differences in Perceived Competence and Social Acceptance among young male and female students with and without DS. Two groups were analysed including 30 participants without DS aged 4 and 5 years old, 15 females $(M=4.40$, sd $=.51 \mathrm{yr}$. $)$ and 15 males $(\mathrm{M}=4.40, \mathrm{sd}=.51 \mathrm{yr}$.) attending the kindergarten and 47 participants with DS aged 8 to 20 years old, 21 females $(\mathrm{M}=14.95$, $\mathrm{sd}=2.50 \mathrm{yr}$. $)$ and 26 males $(\mathrm{M}=14.50, \mathrm{sd}=3.29 \mathrm{yr}$. $)$ attending special schools for children with intellectual disabilities. A Portuguese version of the PSPCSA was used to assess Perceived Competence and Social Acceptance in both groups with and without disability. Results from internal consistency and test/retest reliability measures revealed that this version was appropriate to be used with children with DS from both genders. Gender differences in this study revealed that female students with DS perceived higher levels of Physical Competence but lower levels of Acceptance by their peers when compared with female students without DS. On the other hand, male students with DS felt less accepted by their peers but perceived higher levels of Parental Acceptance when compared with their male colleges without DS.

KEYWORDS: Self-perceptions, Perceived Competence, Social Acceptance, Down Syndrome, Children.

\section{INTRODUCTION}

Over the past decades, the term Selfconcept has been widely accepted in the review of literature in particular after Shavelson, Hubner and Stanton (1976) defined it as a multidimensional construct consisting of separate self-perceptions across different domains (academic versus non academic) and sub domains (social, emotional and physical). Since then different studies have proposed a relationship between one's self-perceptions of ability or competence and individual behaviour.

The theoretical model supporting the Selfconcept assumes that children do not feel competent in all skill domains (Harter, 1982), however they are capable of making meaningful distinctions between different domains (Harter \& Pike, 1984). Usually young children believe that they themselves or others are either all good or all bad, and cannot simultaneously possess apparently contradictory attributes. Young children also 
tend to be positively biased in their descriptions of Self and it is only around the age of 8 years that they develop a sense of Global Self-Worth and start to compare themselves to others in terms of relative attributes (Harter, 1983).

The Pictorial Scale of Perceived Competence and Social Acceptance for Young Children - PSPCSA was developed by Harter and Pike (1984) to measure self-perceptions of competence and acceptance in children aged between 4 to 7 years old, and was initially developed in two different forms, for preschool and kindergarten children, and for first and second grade children. The competence domain is further divided into items measuring perceptions of cognitive and physical competence and the social acceptance domain is divided into items measuring peer acceptance and maternal acceptance.

The study of self-perceptions in educational contexts is of great importance because educators and researchers have long recognised the central role played by the Selfconcept in the educational process (Begley, 1999). Children who are successful in school are likely to hold positive views of themselves, to enjoy more satisfying relationships and to be academically motivated (Burns, 1986). In contrast, children with negative selfperceptions are expected to feel relatively worthless and ineffectual, to reduce their effort or to give up in the face of difficulty (Chapman, 1988).

Relatively little research has been achieved assessing self-perceptions in children and young people with moderate to severe intellectual disability (ID) or with Down Syndrome (DS). This is partly due to measurement difficulties as much of the usual methods used to assess self-esteem are based on questionnaire administration procedures. Recently the PSPCSA has been used in children with ID including children with DS with good results (Begley, 1999; Cuskelly \& de Jong 1996; Glenn \& Cunningham, 2001).

Begley and Lewis (1998) reviewed the methodological procedures for the assessment of Self-concept of children with DS and concluded that the methods based on the
PSPCSA offered the most appropriate mean for assessing the Self-concept of children with DS, because they are designed for the developmentally young, they require minimal language comprehension and minimal language production (Glenn \& Cunhigham, 2001).

Recently Vermeer and Veenhof (1997) translated and adapted Harter's Pictorial Scale and used it in children with cerebral palsy. The Dutch Pictorial Scale of Perceived Competence and Social Acceptance developed in Children with Cerebral Palsy (Vermeer \& Veenhof, 1997 ) is a 40 items scale with four sub-scales of 10 items each rather than the original 24 items scale proposed by Harter \& Pike (1984). Major modifications were introduced in this version aiming to improve children's with disability understanding and attention: (i) the pictures were simplified to increase understanding; (ii) pictures were coloured to maintain children's attention; (iii) children in several pictures were sketched in either a standing or a sitting position in a wheelchair in order to increase understanding when used with children with cerebral palsy and, (iv) some items were also modified using a male figure in order to became more real as well as to assist acceptance of the pictorial representation.

The main purpose of the present study was to examine the sensitivity of the Portuguese version of the Dutch Pictorial Scale of Perceived Competence and Social Acceptance (Vermeer \& Veenhof, 1997) to be used with young students with and without Down Syndrome and assess hypothetical differences in Perceived Competence (Academic and Physical domains) and Social Acceptance (Peers and Maternal/Parental domains) among Portuguese male and female young students with and without Down Syndrome.

\section{METHOD}

\section{Participants}

Participants were 77 students with and without intellectual disabilities (ID) from four districts of centre Portugal. Participants without ID were 30 children, 15 females and 15 males aged 4 and 5 years old $(\mathrm{M}=4.40, \mathrm{sd}=.50 \mathrm{yr}$.) attending the kindergarten. Participants with ID 
were 47 students with Down Syndrome, 21 females and 26 males aged 8 to 20 years old $(\mathrm{M}=14.70, \quad \mathrm{sd}=2.94 \mathrm{yr}$.$) . \quad This subgroup$ presented a mental age between 4 and 7 years old based on the assessment performed by the school psychologists. All subjects from this group attended special schools for children with intellectual disabilities.

\section{Instrument}

A Portuguese version of the preschool kindergarten Dutch Pictorial Scale of Perceived Competence and Social Acceptance (Vermeer \& Veenhof, 1997) previously translated and adapted by Corredeira (2001) for the Portuguese population with disability (PSPCSAp) was used in this study. The major reason for using a translation of the Dutch version rather than the Harter and Pike's original version was based on the modifications introduced for children aged 4 to 6 years which included the modification of the pictures that were simplified to increase understanding among young students with disabilities. These modifications also aimed to assist acceptance by children with disabilities. Separate boys and girls scales were developed for gender matching and in the maternal acceptance scale some items were modified using also a male figure in order to became more real as well as to assist acceptance of the pictorial representation. Due to these modifications, Maternal Acceptance sub-scale is designated for the present study as Parental Acceptance. Validity and reliability of the Dutch version was established in the Netherlands by Vermeer, Lanen, Hendriksen, Speth, and Mulderij (1994) and in Germany by Schwartz, Dzakula, Vermeer and Klughist (1999). The instrument is a 40-item scale with four subscales comprised of ten items each: Cognitive/Academic Competence, Physical Competence, Peer Acceptance, and Maternal/Parental Acceptance. Each answer has a 4-point response format. Higher scores reflect a greater sense of competence or social acceptance. Each subscale total range varies from 10 to 40. The four subscale items are comprised as following: Cognitive/Academic Competence - 1, 5, 9, 13, 17, 21, 25, 29, 33 and 37; Physical Competence - 3, 7, 11, 15, 19,
23, 27,31, 35 and 39; Peer Acceptance - 2, 6, $10,14,18,22,26,30,34$ and 38; and Maternal/Parental Acceptance - 4, 8, 12, 16, 20, 24, 28, 32, 36 and 40.

Two illustrations are presented for each item, typically, a child who is very good and a child who is not very good at the task(s) depicted. Two brief statements, one positive and one negative, are red to each participant for each picture. The child is then asked to choose which of the children from the two statements is most like him or her. After the respondent identifies himself with one of the children, the interviewer asks whether he or she is a lot like that child or a little like that child.

\section{Procedures}

The procedures and the purpose of the study were explained to the participants who were tested individually. The instrument was administered using standardised instructions, in quiet classroom conditions by the same research assistant who was also available to answer any questions. The time required for each child to answer the questionnaire was variable. Participants without Down Syndrome took 10 to 15 minutes to fill the questionnaire while participants with Down Syndrome took more time, ranging from 45 minutes to 1 hour.

\section{Statistical analysis}

Internal consistency of the different scales was assessed using Cronbach's alpha coefficients (Cronbach, 1951). Correlations between variables were calculated using Spearman's correlation analysis. Comparisons between groups were done using non parametric statistics. Mann-Whitney Test was used to compare perception of competence and acceptance among two independent variables, gender and condition (with and without DS). All statistical analyses were performed using SPSS 13.0 Software - Copyright (C) SPSS Inc. - 1989/2004 - with an alpha 5\% significance level.

\section{RESULTS}

\section{Descriptive analyses}

Table 1 presents mean score values for each Self domain from different studies found 
in the review of literature using versions of the preschool - kindergarten Dutch Pictorial Scale of Perceived Competence and Social Acceptance for Young Children with Cerebral Palsy (Vermeer \& Veenhof, 1997) as well as the Pictorial Scale of Perceived Competence and Social Acceptance in Young Children (Harter \& Pike, 1984) in students with and without disability.

\section{Table 1}

Means and standard deviation values for each self-domain from students with and without disability

\begin{tabular}{|l|c|c|c|c|c|c|c|c|}
\cline { 2 - 9 } \multicolumn{1}{c|}{} & \multicolumn{2}{c|}{$\begin{array}{c}\text { Academic } \\
\text { competence }\end{array}$} & \multicolumn{2}{c|}{$\begin{array}{c}\text { Physical } \\
\text { competence }\end{array}$} & \multicolumn{3}{c|}{$\begin{array}{c}\text { Peer } \\
\text { acceptance }\end{array}$} & \multicolumn{2}{c|}{$\begin{array}{c}\text { Parental } \\
\text { acceptance }\end{array}$} \\
\cline { 2 - 10 } \multicolumn{1}{c|}{} & Mean & sd & Mean & sd & Mean & sd & Mean & sd \\
\hline With disability: Present study & 2.64 & .61 & 2.80 & .63 & 2.84 & .49 & 2.85 & .34 \\
\hline Scholtes, Vermeer, \& Meek (2002) & 3.44 & .38 & 3.45 & .45 & 2.99 & .61 & 2.97 & .57 \\
\hline Glenn \& Cunningham (2001) & 3.95 & .14 & 3.90 & .28 & 3.85 & .39 & 3.80 & .40 \\
\hline Cuskelly \& de Jon (1996) & 3.60 & .55 & 3.60 & .54 & 3.30 & .43 & 3.90 & .55 \\
\hline & & & & \multicolumn{5}{|c|}{} \\
\hline Without disability: Present study & 2.80 & .35 & 2.45 & .44 & 3.16 & .31 & 2.73 & .33 \\
\hline Harter \& Pike (1984) & 3.50 & .43 & 3.30 & .43 & 2.90 & .56 & 3.00 & .59 \\
\hline
\end{tabular}

Descriptive values from Table 1 revealed that subjects from our study presented the lowest self-perceptions mean values from all the studies analysed. When compared with other students Portuguese young students with and without DS perceived themselves as less competent and less accepted by others. In spite of the lower feeling expressed all students scored positively, i.e., above 2.5 in a scale from 1 to 4, except for Physical Competence in the group of young students without DS that scored an average value of 2.45 .

Children with DS revealed higher levels of perceived Physical Competence and Parental Acceptance than children without DS. On the other hand, children without DS presented higher levels of perceived Academic Competence and Peer Acceptance than their colleges with DS.

Table 2

Descriptive score values from young students with and without Down Syndrome by gender

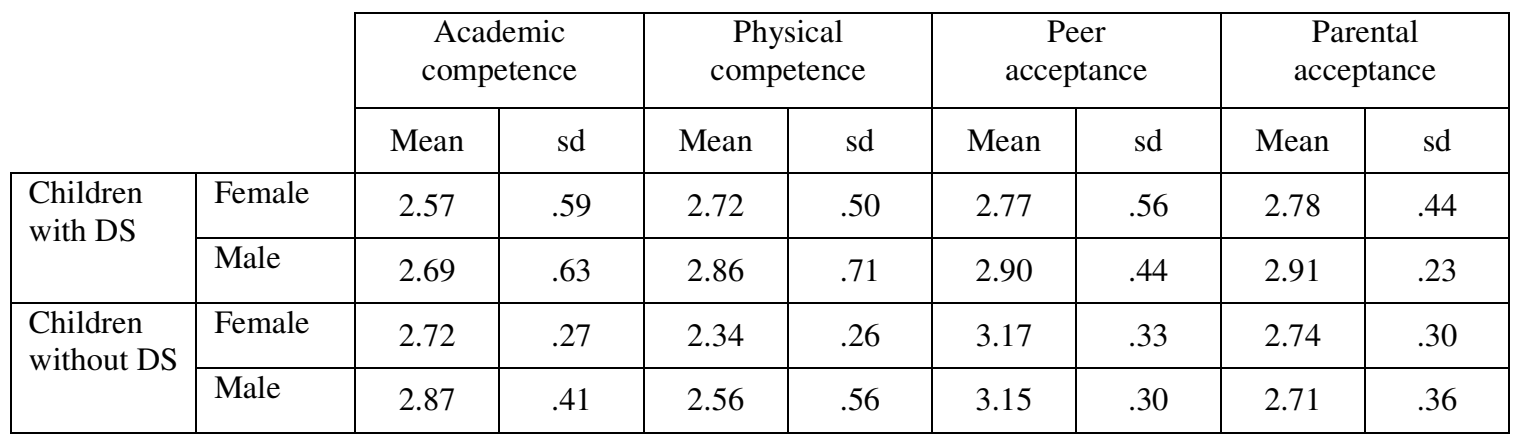

Gender differences between participants with and without DS revealed that males presented higher levels of Perceived Competence (Physical and Academic) than females in both groups with and without DS. With regard to Acceptance, male students with DS present higher levels of Perceived Acceptance (Peers and Maternal) than females, 
however in the group without DS females scored higher than males in both sub-domains with females expressing higher levels of confidence in their Social Acceptance. In spite of the differences in average found between constructs for each subgroup no significant statistical differences were found among them.

In spite of the small sample size exploratory factor analysis (EFA) with varimax rotation was used in both groups with and without DS to determine the extent to which the original four factors structure could be replicated with the PSPCSAp. Factor loadings below 0.4 were eliminated for the sake of clarity and factor solutions explaining less than $40 \%$ of item covariance and fewer than three items in each factor were not given further consideration (Tinsley \& Tinsley, 1987). Descriptive statistics and factor solutions were compared with those obtained in the original instrument (Harter \& Pike, 1984) as well as in other studies with the Dutch and German versions (Vermeer et al., 1994 and Schwartz et al., 1999).

Factors solution for young students without DS $(n=30)$ revealed four factors that explained $47.31 \%$ of the total variance among the subscales items, however also revealed an unclear organization that did not support the original factor structure showing a high number of cross loadings among factors: i) factor 1 included items from Peers Acceptance as well as from Physical Competence, ii) factor 2 included items from Academic Competence as well as from Peers and Parental Acceptance, iii) factor three included items from Parental Acceptance and iv) factor 4 included items from Physical Competence.

On the other hand, the factors solution for young students with DS $(n=47)$ was much more clear.

Table 3 presents principal components factor loadings for PSPCSAp items from young students with DS. EFA revealed four initial factors that explained $57.35 \%$ of the total variance among the subscale items. Results revealed a clear definition of two factors Physical and Academic Competence - as subscales for the Perceived Competence and a third factor including items from Peers and Parental Acceptance - as a unique subscale for Social Acceptance. It seems that participants with DS may perceive and value acceptance feelings in an undifferentiated way, whether they come from friends and peers or from parents and close family. Present results should be interpreted carefully as the merge of these two subscales (Peers and Parental Acceptance) in a unique subscale may be a consequence of sample size effects and must be tested in future studies.

\section{Validity and Reliability}

Table 4 presents internal consistency measures undertaken for each subscale using Cronbach Alpha values. Internal consistency coefficients ranged from .44 to .88 in children with DS and from .05 to .59 in children without DS. The Cronbach Alpha coefficient values from all scale domains in the group without DS were low, especially for Perceived Acceptance ranging from .35 to .39 for Parental Acceptance and Peer Acceptance, respectively. Test/retest reliability was measured using Pearson's correlations between the sum scores from two measurements over a two-weeks period $(n=12)$ and ranged from $r=.70$ to .81 .

\section{Hierarchical Structure}

Table 5 presents correlation coeff-icients from Portuguese young students with and without Down Syndrome (DS) and provides evidence for the hypothesised relationship between Perceived Competence and Perceived Acceptance domains.

Correlation coefficients results presented in Table 5 ranged from $\mathrm{r}=.20$ to $\mathrm{r}=.35$ for children without DS and from $r=.02$ to $r=.76$ for children with DS. 
Table 3

Principal components factor loadings for PSPCSAp items - students with DS $(n=47)$

\begin{tabular}{|c|c|c|c|c|c|}
\hline Sub-scale & Item $\mathrm{N}^{\circ}$ & $\begin{array}{c}\mathrm{F} 1 \\
\text { loadings }\end{array}$ & $\begin{array}{c}\mathrm{F} 2 \\
\text { loadings }\end{array}$ & $\begin{array}{c}\mathrm{F} 3 \\
\text { loadings }\end{array}$ & $\begin{array}{c}\mathrm{F} 4 \\
\text { loadings }\end{array}$ \\
\hline \multirow{7}{*}{$\begin{array}{c}\text { PHYSICAL } \\
\text { COMPETENCE }\end{array}$} & 3 & .57 & \multirow{7}{*}[-.46]{} & & \\
\hline & 11 & .81 & & & \\
\hline & 15 & .74 & & & \\
\hline & 23 & .72 & & & \\
\hline & 27 & .74 & & & \\
\hline & 31 & .62 & & & \\
\hline & 35 & .76 & & & \\
\hline \multirow{10}{*}{$\begin{array}{c}\text { PEERS } \\
\text { ACCEPTANCE } \\
+ \\
\text { PARENTAL } \\
\text { ACCEPTANCE }\end{array}$} & 2 & & .45 & \multirow{10}{*}[.45]{} & \\
\hline & 14 & & .74 & & \\
\hline & 18 & & .48 & & \\
\hline & 22 & & .60 & & \\
\hline & 30 & & .62 & & \\
\hline & 12 & [.49] & -.65 & & \\
\hline & 16 & & .57 & & \\
\hline & 24 & & .80 & & \\
\hline & 32 & & .63 & & \\
\hline & 40 & & .71 & & \\
\hline \multirow{4}{*}{$\begin{array}{c}\text { ACADEMIC } \\
\text { COMPETENCE }\end{array}$} & 9 & & & .83 & \\
\hline & 17 & & & .74 & \\
\hline & 21 & & & .76 & \\
\hline & 25 & & & .62 & \\
\hline \multirow{3}{*}{$\mathrm{F} 4$} & 8 & & & & -.55 \\
\hline & 13 & & & & -.66 \\
\hline & 36 & & {$[.52]$} & & .56 \\
\hline Eigenvalue & & 7.29 & 6.75 & 6.23 & 2.67 \\
\hline$\%$ Variance & & 18.23 & 16.88 & 15.58 & 6.66 \\
\hline Cum. \% Variance & & 18.23 & 35.11 & 50.69 & 57.35 \\
\hline
\end{tabular}

Note

For clarity only loadings for the expected factors and unexpected loadings (cross loadings in brackets) exceeding .40 are included.

Table 4

Coefficient Cronbach Alpha values for participants with and without Down Syndrome

\begin{tabular}{|c|c|c|c|c|c|c|c|c|}
\hline & \multicolumn{2}{|c|}{$\begin{array}{c}\text { Academic } \\
\text { competence }\end{array}$} & \multicolumn{2}{c|}{$\begin{array}{c}\text { Physical } \\
\text { competence }\end{array}$} & \multicolumn{2}{c|}{$\begin{array}{c}\text { Peer } \\
\text { acceptance }\end{array}$} & \multicolumn{2}{c|}{$\begin{array}{c}\text { Parental } \\
\text { acceptance }\end{array}$} \\
\hline & with DS & $\begin{array}{c}\text { without } \\
\text { DS }\end{array}$ & with DS & $\begin{array}{c}\text { without } \\
\text { DS }\end{array}$ & with DS & $\begin{array}{c}\text { without } \\
\text { DS }\end{array}$ & with DS & $\begin{array}{c}\text { without } \\
\text { DS }\end{array}$ \\
\hline Alpha & .85 & .33 & .88 & .59 & .82 & .39 & .44 & .35 \\
\hline
\end{tabular}


Table 5

Correlation coefficients from Portuguese students with and without DS

\begin{tabular}{|c|c|c|c|c|c|}
\hline \multirow{2}{*}{ Without DS } & & ACCOMP & PHYCOMP & PEERACCEP & \multirow[t]{2}{*}{ MATACCEP } \\
\hline & & & & & \\
\hline & ACCOMP & 1 & & & \\
\hline & PHYCOMP & .24 & 1 & & \\
\hline & PEERACCEP & -.23 & -.35 & 1 & \\
\hline & PARACCEP & .20 & .28 & -.21 & 1 \\
\hline \multicolumn{6}{|l|}{ With DS } \\
\hline & ACCOMP & 1 & & & \\
\hline & PHYCOMP & $.76 * *$ & 1 & & \\
\hline & PEERACCEP & .06 & -.12 & 1 & \\
\hline & PARACCEP & -.03 & .02 & $.59 * *$ & 1 \\
\hline
\end{tabular}

$* *$ Coefficients significant at .01

The global level of correlations found for both groups is quite low however two significant correlations were found for children with DS, $\mathrm{r}=.76, \mathrm{p}<.01$, between Academic and Physical Competence and, $\mathrm{r}=.59, \mathrm{p}<.01$, between Peer and Parental Acceptance subscales. No correlations were found between Perceived Competence and Perceived Acceptance domains.

\section{Comparison between groups}

Differences between Portuguese students with $(n=47)$ and without $(n=30)$ Down Syndrome (DS) were analysed using nonparametric statistics. Mann-Whitney Test results for Perceived Competence and Perceived Acceptance revealed significant statistical differences for Physical Competence $(\mathrm{U}=481.00 ; \quad \mathrm{Z}=-2.345 ; \quad \mathrm{p}<.05), \quad$ Peer Acceptance $(\mathrm{U}=431.00 ; \mathrm{Z}=-2.880 ; \mathrm{p}<.01)$ and Parental Acceptance $(\mathrm{U}=476.00 ; \mathrm{Z}=-$ $2.404 ; \mathrm{p}<.05)$ between students with and without DS.

Gender differences between groups with and without disability (DS) revealed that significant statistical differences were found for Physical Competence $(\mathrm{U}=87.00 ; \mathrm{Z}=-2.254 ; \mathrm{p}<.05)$ and Peer Acceptance $(\mathrm{U}=96.50 ; \mathrm{Z}=-1.973$; $\mathrm{p}<.05)$ between Portuguese female students with and without Down Syndrome, and for Peer Acceptance $(U=118.50 ; \quad Z=-2.089$; $\mathrm{p}<.05)$ and Parental Acceptance $(\mathrm{U}=108.00$; $\mathrm{Z}=-2.368 ; \mathrm{p}<.05)$ between male students with and without disability.

\section{DISCUSSION}

The major purpose of this study was to determine whether a Portuguese version of the Dutch Pictorial Scale of Perceived Competence and Social Acceptance developed in children with cerebral palsy is a sensitive instrument to be used in children with Down Syndrome.

The results from both internal consistency and test/retest reliability measures revealed that this Portuguese version of the PSPCSAp is appropriate to be used with children with DS from both genders, however the use of this version in students without disability has to be taken carefully because Cronbach Alpha values for both female and male groups without disability ranged from weak to moderate. These results may have been influenced by the type of modifications introduced in the scale to adjust it to children with disability that may have been perceived as confusing for groups without disability. Cronbach Alpha values for groups with DS followed a similar range and pattern to the one reported by Scholtes, Vermeer and Meek (2002), Vermeer and Veenhof (1997) and Schartz et al. (1999) for English, Dutch and German versions of this instrument.

Further evidence for construct validity of the instrument has to be established using factor analysis. Unfortunately, a major caveat in the present study is the influence of the sample size on the reported factor structure. This caveat has to be set against the problems of young children with DS and the instrumental 
limitations researchers usually have to find adequate instruments for psychological assessment. This preliminary analysis is not sufficient to fully confirm the validity and reliability of PSPCSAp, however it fully confirms the sensitivity of the instrument to assess Perceived Competence and Social Acceptance.

A second aim of the present study was to assess hypothetical differences in Perceived Competence and Social Acceptance between male and female subgroups with and without disability. Descriptive statistics from different constructs (Academic Competence, Physical Competence, Peers Acceptance and Parental Acceptance) revealed that Portuguese students with and without disability reported the lowest levels of Perceived Competence and Social Acceptance of all the studies analysed in the review of the literature using groups with identical characteristics. These results do not fully support those suggested by Cuskelly and de Jong (1996) and Glenn and Cunningham (2001) with young students with DS that rated themselves very positively in all domains. According to Glenn and Cunningham (2001) the participants were not responding randomly or preseverating but rather searching for the positive statement and than choosing the highest rating.

However, this lower level of Selfperceptions is quite familiar in studies involving different Portuguese groups. Ferreira and Fox (2007) found a similar pattern among Portuguese secondary school and university students and identical results were also confirmed among other Portuguese groups with and without physical disability (Ferreira, 2006; Ferreira et al., in press). Furthermore, the range of mean values followed a similar pattern to the one reported by Corredeira (2001) when developing the Portuguese version of the PSPCSAp. In spite of the lower mean values, around average, Portuguese students with and without DS perceived themselves as positively competent and positively accepted by others (both peers and parents).

According to Harter (1999) "you will probably find what we have found with normal 4-year-olds, namely that scores are quite high since they confuse the wish to be competent with their actual abilities". Most young people at this developmental level may see their abilities very positively, and the pictorial scale reflects that level of self-perception, however a problem may arise from this in the sense that results may be valid but not very useful considering that young students are overvaluing their own feelings.

Based on the results from the present study an important question raises among Portuguese young students with and without DS. Are the lower levels of Perceived Competence and Social Acceptance due to the pattern described for the Portuguese population or is it because this particular group does not overvalue their individual feelings about Competence and Acceptance, as suggested by Harter (1999), providing a more realistic view of themselves. Further research is needed to answer this question.

In the present study children with DS reported higher levels of Perceived Physical Competence and Parental Acceptance than children without DS. On the other hand, children without DS reported higher levels of Perceived Academic Competence and Peer Acceptance than their colleges with DS. These results are different from those reported by Begley (1999) in students with DS and Harter and Pike (1984) in students without disability that in both cases tend to rate themselves higher for the two Competence domains and lower for the two Acceptance domains.

A higher level of perception in the Competence domain might be expected because Competence judgments are argued to be more related to appraisals of the Self than Social Acceptance, which also takes in account appraisals about the characteristics of others (Harter \& Pike, 1984). In the present study students reported higher levels on Social Acceptance than in Perceived Competence, except for Academic Competence in the group without disability that scored also high. Portuguese students with DS scored particularly high in Peer Acceptance and Parental Acceptance revealing high levels of Self-perception about the way they are accepted by their colleges and by their close 
family members. These results may be justified by the fact that all participants with DS were attending special schools for children with intellectual disabilities, with a friendly and inclusive environment, where children are viewed, educated and loved as children and the focus on the disability is secondary. Results might be slightly different if participants belong to mainstream schools, where students and professionals may develop more frequent segregational attitudes towards children with DS as a reflex of a less inclusive environment. Finally, results from students without DS seem quite interesting as they report high values of Self-perceptions in Academic Competence, Peer Acceptance and also Parental Acceptance. Considering the age-group assessed in this study (4-5 yrs. old) results seem quite consistent considering the aims of the national educational curriculum for these age-groups. The national educational curriculum at this ages focus attention on promoting Academic Competence, based on the idea of autonomy to perform different educational tasks (such as drawing, painting, cutting out and performing the first graphemes) as well as promoting Social Acceptance in particular among peers through the development of interaction activities between children and developing the idea of sharing toys, books and school didactic materials as well as participating in cooperative educational activities.

Finally, gender differences also revealed that female students with DS perceived higher levels of Physical Competence but lower levels of Acceptance by their peers when compared with female students without DS. Furthermore, male students with DS feel less accepted by their peers but perceive higher levels of Parental Acceptance when compared with their male colleges without DS.

\section{REFERENCES}

Begley, A. (1999). The self-perceptions of pupils with Down Syndrome in relation to their academic competence, physical competence and social acceptance. International Journal of Disability, Development and Education, 46(4), 515-529.
Begley, A., \& Lewis, A. (1998). Methodological issues in the assessment of the self-concept of children with Down Syndrome. Child Psychology and Psychiatry Review, 3(1), 33-40.

Burns, R. B. (1986). The self-concept: Theory, measurement, development and behavior. Essex: Longman.

Chapman, J. (1988). Learning disabled children's self-concepts. Review of Educational Research, 58(3), 347-371.

Corredeira, R. (2001). Competência Percebida $e$ Aceitação Social em Crianças com Paralisia Cerebral: Tradução e adaptação da Pictorial Sclae ans Social Acceptance in Chlidren with Cerebral Palsy para a realidade portuguesa. Tese de dissertação de mestrado, Faculdade de Ciências do Desporto e Educação Física, Universidade do Porto.

Cronbach, L. J. (1951). Coefficient alpha and the internal structure of tests. Psycho-metrika, 16, 297-334.

Cuskelly, M., \& de Jong, I. (1996). Selfconcept in children with Down Syndrome. Down Syndrome: Research and Practice, 4(2), 59-64.

Cuskelly, M. (2004). The Evolving Construct of Intellectual Disability: is everything old new again? International Journal of Disability, Development and Education, 51(1), 117-123.

Ferreira, J. P. (2006). Physical Self and Global Self-esteem in Wheelchair Sport Participants: A mixed method approach. Coimbra: FCDEF-UC, Centro de Estudos Biocinéticos.

Ferreira, J. P, \& Fox, K. R. (2007). An investigation into the structure, reliability, and validity of the Physical Self-Perception Profile in non-English spoken settings. International Journal of Applied Sport Sciences, 19(1), 25-46.

Ferreira, J. P., Gaspar, P. M., Fox, K. R., Campos, M. J., \& Senra, C. M. (in press) Autoeficácia, Competência Física e Autoestima em praticantes de basquetebol com e sem deficiência. Submitted to Revista Brasileira de Educação Física e Esporte, Universidade de São Paulo.

Glenn, S., \& Cunningham, C. (2001). Evaluation of Self by Young People with 
Down Syndrome. International Journal of Disability, Development and Education, 48(2), 163-177.

Harter, S. (1982). The Perceived Competence Scale for Children. Child Development, 53, 87-97.

Harter, S. (1999). The Construction of the Self. A Developmental Perspective. New York. The Guilford Press.

Harter, S., \& Pike, R. (1984). The Pictorial Scale of Perceived Competence and Social Acceptance for Young Children. Child Development, 55, 1969-1982.

Scholtes, V., Vermeer, A., \& Meek, G. (2002). Measuring perceived competence and social acceptance in children with cerebral palsy. European Journal of Special Needs Education, 17(1), 77-87.

Schwartz, D., Dzakula, A., Vermeer, A., \& Klughist, I. (1999). Die Messung der Selbstwahrgenomenen Kompetenz von Kindern und Jugendlichen mit CerebralParese. Motorik, 22, 64-72.

Shavelson, R. J., Hubner, J. J., \& Stanton, G. C. (1976). Validation of construct interpretations. Review of Educational Research, 46, 407-441.

Tinsley, H., \& Tinsley, D. (1987). Uses of factor analysis in counselling psychology research. Journal of Counselling Psychology, 4(34), 414-424.

Vermeer, A., Lanen, W., Hendriksen, J., Speth, L., \& Mulderij, K. (1994). Measuring perceived competence in children with cerebral palsy. In J. H. A. van Rossum \& J. I. Laszlo (Eds.), Motor development: Aspects of normal and delayed development (pp. 133-144). Amsterdam: VU University Press.

Vermeer, A., \& Veenhof, C. (1997). The Dutch Pictorial Scale of Perceived Competence and Social Acceptance for Children with Cerebral Palsy: A reliability and validation study. European Master Degree in Adapted Physical Activity, Vrije Universiteit Amsterdam.

Corresponding author's e-mail address: mjcampos@fcdef.uc.pt

\section{ÜBERPRÜFUNG DER WAHRGENOMMENEN KOMPETENZ UND SOZIALEN AKZEPTANZ VON JUNGEN PORTUGIESISCHEN SCHÜLER/INNEN MIT UND OHNE DOWN SYNDROM: EINE VORLÄUFIGE ANALYSE}

(Resümee)

Die Untersuchung des Selbstkonzepts in Gruppen von Menschen mit Behinderung ist ein wichtiges Forschungsgebiet in Portugal und es werden mehr Belege benötigt. So fehlen z.B. Erkenntnisse über wahrgenommene Kompetenzen und soziale Akzeptanz von jungen Schüler/innen mit Down Syndrom (DS). Das Hauptziel dieser Untersuchung war die Überprüfung der Reliabilität der portugiesischen Version der Dutch Pictoral Scale of Preceived Competence and Social Acceptance (DPSPCSA, Vermeer \& Veenhof, 1997) in der Anwendung bei Kindern mit und ohne Down Syndrom. Zudem sollten hypothetische Unterschiede wahrgenommener Kompetenz und sozialer Akzeptanz bei jungen männlichen und weiblichen Schüler/innen mit und ohne DS eingeschätzt werden. Es wurden in zwei Gruppen einerseits 30 Teilnehmer/innen ohne DS im Alter von 4 und 5 Jahren, 15 weiblich $(M=4.40$, sd = 0.51 J.) und 15 männlich $(M=4.40$, sd $0.51 \mathrm{~J}$.$) , die$ einen Kindergarten besuchten, analysiert. Die andere Gruppe umfasste 47 Teilnehmer/innen mit DS im Alter von 8 bis 20 Jahren, 21 weiblich $(M=14.95$, $\mathrm{sd}=2.50 \mathrm{~J}$. $)$ und 26 männlich $(\mathrm{M}=14.50$, $\mathrm{sd}=3.29 \mathrm{~J}$.), die eine Sonderschule für Kinder mit intellektueller Behinderung besuchten. Zur Erhebung der wahrgenommenen Kompetenz und der sozialen Akzeptanz der Teilnehmer/innen wurde in beiden Gruppen die portugiesische Version des PSPCSA verwendet. Resultate aus internen Konsistenz- und Test/Retest-Messungen ergaben, dass diese Version für die Anwendung bei Kindern mit DS beider Geschlechter geeignet erscheint. Folgende Geschlechtsunterschiede 
konnten herausgearbeitet werden: weibliche Schülerinnen mit DS nahmen ein höheres Level an physischen Kompetenzen wahr, hatten aber ein geringeres Level der Akzeptanz bei Gleichaltrigen im Vergleich zu weiblichen Schülerinnen ohne DS. Auf der anderen Seite fühlten sich männliche Schüler mit DS bei Gleichaltrigen weniger akzeptiert, nahmen aber eine höhere elterliche Akzeptanz wahr im Vergleich zu ihren männlichen Kollegen ohne DS.

SCHLÜSSELWÖRTER: Selbstbild, wahrgenommene Kompetenz, soziale Akzeptanz, Down Syndrom, Kinder.

\title{
COMPETENCES PERÇUES ET EVALUATION DE L'ACCEPTATION SOCIALE DES JEUNES ELEVES PORTUGAIS TRISOMIQUES 21 OU NON : UNE ANALYSE PRELIMINAIRE
}

\author{
(Résumé)
}

L'étude sur la perception de soi dans les groupes en situation de handicap est un domaine émergeant de la recherche au Portugal et il est nécessaire de valider le test des Compétences Perçues et l'Acceptation Sociale des jeunes élèves trisomiques 21. L'objectif principal de cette étude était d'évaluer la fiabilité de la version portugaise de l'Echelle Illustrée Allemande des Compétences Perçues et de l'Acceptation Sociale (the Dutch Pictorial Scale of Perceived Competence and Social Acceptance, PSPCSA) (Vermeer \& Veenhof, 1997) pour être utilisée chez les enfants trisomiques ou non. Le deuxième but était d'évaluer les différences potentielles dans les Compétences Perçues et l'Acceptation Sociale parmi les jeunes élèves garçons et filles avec ou sans trisomie 21. Deux groupes ont été étudiés comprenant 30 participants sans trisomie âgés de 4 et 5 ans, 15 filles $(\mathrm{M}=4.40, \mathrm{sd}=.51 \mathrm{yr}$. $)$ et 15 garçons $(\mathrm{M}=4.40, \mathrm{sd}=.51 \mathrm{yr}$. $)$ en écoles maternelles et 47 participants trisomiques âgés de 8 à 20 ans, 21 filles $(M=14.95$, sd $=2.50 \mathrm{yr}$.) et 26 garçons $(\mathrm{M}=14.50$, $\mathrm{sd}=3.29 \mathrm{yr}$.) intégrés en écoles spéciales pour enfants ayant une déficience intellectuelle. Une version portugaise du PSPCSA a été utilisée pour évaluer les Compétences Perçues et l'Acceptation Sociale dans les groupes avec et sans trisomie 21. Les résultats de la cohérence interne et des tests de mesures de fiabilité révèlent que cette version est appropriée pour être utilisée chez des enfants trisomiques des deux sexes. Les différences de genres dans cette étude révèlent que les élèves trisomiques 21 de sexe féminin ont un plus haut niveau de Compétence Physique mais un plus faible niveau d'Acceptation par leurs pairs lorsqu'on les compare avec les filles sans trisomie. D'un autre côté, les élèves trisomiques 21 de sexe masculin se sentent moins acceptés par leurs pairs mais ont un plus haut niveau d'Acceptation Parentale lorsqu'on les compare avec les garçons non trisomiques.

MOTS CLEFS : Perception de soi, Compétences perçues, Acceptation sociale, Trisomie 21, Enfants. 